\title{
Ocorrência de Pectobacterium carotovorum subsp. carotovorum em pseudocaule da bananeira em Minas Gerais
}

\author{
Nilvanira Donizete Tebaldi ${ }^{1}$, Lara Caroline Borges Moreira Mota ${ }^{1}$
}

\begin{abstract}
${ }^{1}$ Instituto de Ciências Agrárias, Universidade Federal de Uberlândia, Av. Amazonas s/n, Bloco 4C-127, Campus Umuarama, CEP 38.400-902, Uberlândia, MG, Brazil

Autor para correspondência: Nilvanira Donizete Tebaldi (nilvanira@iciag.ufu.br)

Data de chegada: 20/02/2014. Aceito para publicação em: 11/03/2014.
\end{abstract}

$10.1590 / 0100-5405 / 1973$

Em 2013, no município de Jaiba, MG foram observadas plantas de bananeira (Musa spp.) "Prata Anã”, com sintomas de murcha das folhas centrais seguida de seca e podridão mole do pseudocaule (Figura 1). A partir do tecido do pseudocaule infectado foi realizado o isolamento bacteriano em meio 523, no Laboratório de Bacteriologia Vegetal do Instituto de Ciências Agrárias da Universidade Federal de Uberlândia, cuja colônia isolada apresentou as seguintes características (SCHAAD et al. Laboratory guide for identification of plant pathogenic bacteria. St. Paul. APS, 2001, p.56-72): bactéria Gram negativa; oxidação/ fermentação: anaeróbica; com colônias de coloração branca em meio 523 após 2 dias, a $28{ }^{\circ} \mathrm{C}$; crescimento a $37{ }^{\circ} \mathrm{C}$; oxidase, hidrólise do amido, redução de açúcar à partir da sacarose, atividade da fosfatase, citrato e produção de indol todos negativos; produção de ácidos à partir do sorbitol, rafinose e lactose positivos, utilização de arabinose, galactose, glicose, glicerol, sacarose, maceração da batata e catalase todos positivos e reação de hipersensibilidade positivo em tomate cv. Santa Clara. Para o teste de patogenicidade, três plantas de bananeira cultivar Prata Anã foram inoculadas, como auxílio de uma agulha e seringa, com uma suspensão bacteriana de $10^{9} \mathrm{UFC} \mathrm{mL}^{-1}\left(\mathrm{OD}_{550}=0,5\right)$ introduzida no pseudocaule. Como controle, plantas foram inoculadas com solução salina $0,85 \%$. As plantas permaneceram em câmara úmida por $24 \mathrm{~h}$ antes e após a inoculação e mantidas em casa de vegetação. Após 4 dias foram reproduzidos os sintomas de descoloração interna do pseudocaule da bananeira, de onde a bactéria foi reisolada. Nas plantas controle não foram observados sintomas. As características permitiram identificar a bactéria como Pectobacterium carotovorum subsp. carotovorum agente causal de murcha das folhas e podridão mole do pseudocaule da bananeira. A podridão mole, causada pela bactéria P. carotovorum subsp. carotovorum (Jones 1901) Waldee 1945 emend. Hauben, Moore, Vauterin, Steenackers, Mergaert, Verdonck \& Swings 1999 (HAUBEN et al. International Journal of Systematic Bacteriology, v.49, p.1-3, 1999), foi descrita no Brasil afetando diversas culturas (MALAVOTA JR. et al. Summa Phytopathologica, v.34, s.suppl., 2008), entre estas a cultura da bananeira nas regiões Nordeste e Norte do Brasil (PEIXOTO et al. Fitopatologia Brasileira, v.20, p.282, 1995; PEREIRA \& NUNES, Fitopatologia Brasileira, v.13, p.70-71, 1988). Os sintomas de murcha das folhas centrais podem ser confundidos com os sintomas do mal-do-panamá (Fusarium oxysporum f.sp. cubense) e o moko (Rasltonia solanacearum). A caracterização e identificação de fitobactérias auxiliarão no manejo adequado da doença no campo. Este é o primeiro relato de $P$. carotovorum subsp. carotovorum causando murcha das folhas e podridão mole do pseudocaule da bananeira em Minas Gerais. O isolado encontra-se depositado na coleção de fitobactérias do Instituto de Ciências Agrárias da Universidade Federal de Uberlândia, com o código UFU E65.

\section{AGRADECIMENTO}

Á Célio Vinicius da Mota Junior pelo fornecimento de mudas de bananeira para inoculação e Carlos Hamilton Jorge pelo envio das fotos com sintomas da doença.
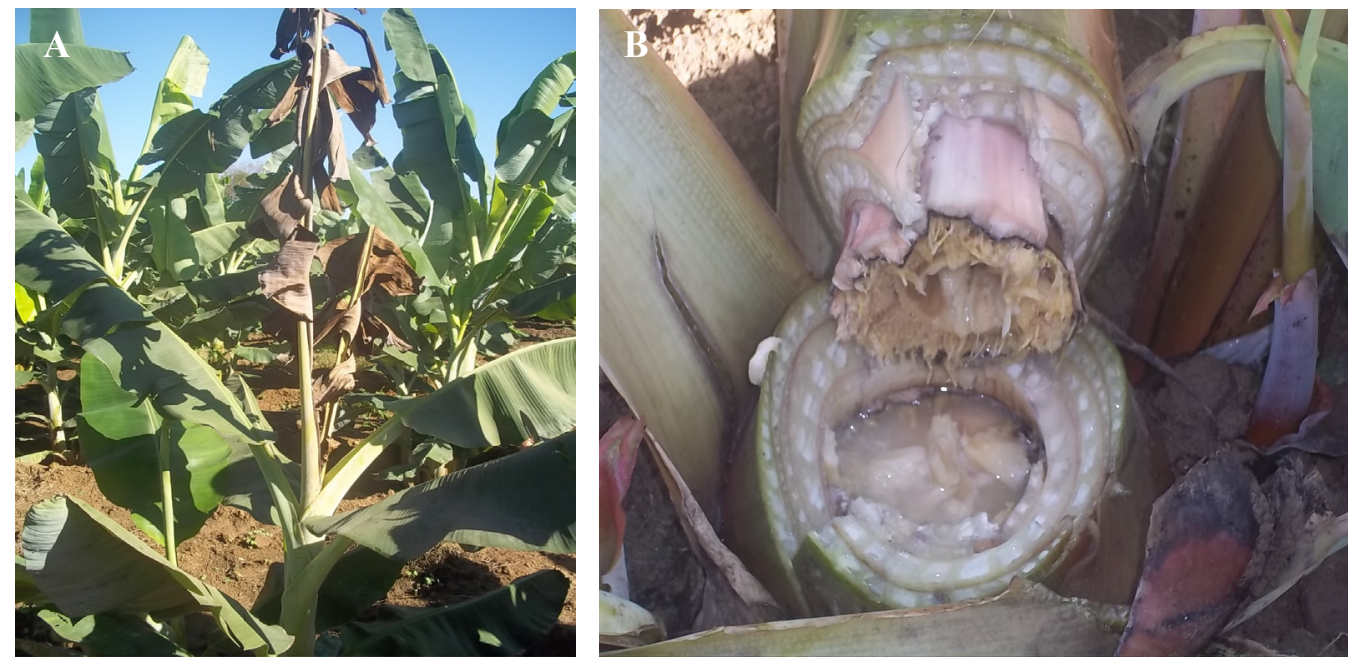

Figura 1. Sintomas de murcha das folhas centrais (A) e de podridão mole do pseudocaule (B) da bananeira, causados por Pectobacterium carotovorum subsp. carotovorum. 